Agro Ekonomi Vol. 27/No. 2, Desember 2016

\title{
PENGARUH PERAN PETUGAS LAPANG TERHADAP PARTISIPASI PETANI DALAM PENGEMBANGAN MODEL DESA KAKAO DI KABUPATEN GUNUNGKIDUL
}

\author{
Farmer Participation in The Development of Cocoa Village Model in \\ Gunungkidul
}

\author{
Kurnia Tanjungsari ${ }^{1}$, Sunarru Samsi Hariadi ${ }^{2}$, Endang Sulastri ${ }^{3}$ \\ ${ }^{1}$ Bappeda Daerah Istimewa Yogyakarta \\ ${ }^{2}$ Dosen Fakultas Pertanian Universitas Gadjah Mada \\ ${ }^{3}$ Dosen Fakultas Peternakan Universitas Gadjah Mada \\ tanjungsari89@gmail.com
}

Diterima tanggal : 10 Agustus 2016 ; Disetujui tanggal : 20 September 2016

\begin{abstract}
The development of cocoa village model are activities that make the region an area of cocoa as a pilot model by optimizing cultivation (on farm), and post-harvest processing (off farm), and the strengthening of human and institutional resources. This activity has a principle of the active participation of farmers. In order for farmers to have an active participation in the development of the model village of cocoa required field officers role as a communicator, motivator, organizer, facilitator, and consultant. The research aimed to find out the influence of the role of field officers on the Farmer Participation in The Development of Cocoa Village Model in Gunungkidul. The basic method of research was descriptive analysis with quantitative approach. The research took place purposively at 4 groups offarmers in Patuk Subdistrict, Gunungkidul with the consideration that the programs was only done at the site. 120 samples was taken by simple random sampling method as respondents were used and then the data analyzed with simple linear regression. The results showed that the role of field officers affected the farmers' participation in the program, which means increasingly frequent field officers carry out its role, the participation offarmers will be increased so that the role of field officers need to be optimized especially role as a motivator.
\end{abstract}

Keywords: development of cocoa village model, Gunungkidul, participation, the role of field officers

\section{INTISARI}

Pengembangan model desa kakao adalah kegiatan yang menjadikan suatu kawasan kakao sebagai kawasan model percontohan dengan melakukan optimalisasi budidaya (on farm), pengolahan dan pasca panen (off farm), serta penguatan sumber daya manusia dan kelembagaan. Kegiatan ini memiliki prinsip partisipasi aktif dari petani. Agar petani memiliki partisipasi yang aktif dalam pengembangan model desa kakao, diperlukan peran petugas lapang sebagai komunikator, motivator, organisator, fasilitator, dan konsultan. Penelitian ini bertujuan untuk mengetahui pengaruh peran petugas lapang terhadap partisipasi petani dalam pengembangan model desa kakao di Kabupaten Gunungkidul. Metode dasar penelitian adalah deskriptif analitis dengan pendekatan kuantitatif. Lokasi penelitian ditentukan secara purposive di 4 kelompok tani yang ada di Kecamatan Patuk, Kabupaten Gunungkidul 
dengan pertimbangan bahwa pengembangan model desa kakao ini hanya dilakukan di lokasi tersebut. Jumlah sampel yang digunakan 120 responden yang diambil secara simple random sampling. Data dianalisis dengan regresi linier sederhana. Hasil penelitian menunjukkan bahwa peran petugas lapang berpengaruh terhadap partisipasi petani dalam pengembangan model desa kakao di Kabupaten Gunungkidul, yang berarti semakin sering petugas lapang menjalankan perannya, maka partisipasi petani akan meningkat sehingga peran petugas lapang perlu dioptimalkan terutama peran sebagai motivator.

Kata kunci : Gunungkidul, partisipasi, pengembangan model desa kakao, peran petugas lapang

\section{PENDAHULUAN}

Kakao (Theobroma cacao L) telah menjadi salah satu komoditas unggulan sektor perkebunan di Kabupaten Gunungkidul. Kondisi topografi, jenis tanah dan agroklimat di Kabupaten Gunungkidul sangat mendukung untuk pengembangan tanaman kakao. Kakao dapat memberi kontribusi yang cukup berarti bagi perekonomian petani terutama disaat tanaman lain tidak menghasilkan, kakao dapat membantu karena produksinya yang terus menerus sepanjang tahun.

Penanaman kakao di Kabupaten Gunungkidul pada umumnya dilakukan di lahan pekarangan yang tidak terlalu jauh dengan rumah. Rata-rata pemilikan lahan petani seluas $0,27 \mathrm{Ha}$, yang terdiri dari pekarangan, kebun dan tegalan. Menurut data statistik Dinas Kehutanan dan Perkebunan DIY tahun 2012, produktivitas tanaman Kakao di Kabupaten Gunungkidul sebesar 0,58 ton/tahun.

Kondisi kakao saat ini mengalami berbagai kendala antara lain: adanya serangan organisme pengganggu tanaman terutama Penggerek Buah Kakao (PBK), Helopeltis, busuk buah dan Vascular Streak Dieback (VSD), mutu biji kakao yang rendah dan beragam, produktivitas kakao menurun, minimnya perawatan tanaman yang berupa pemangkasan yang menyebabkan banyak tumbuh cabang autotrop sehingga berakibat pohon semakin tinggi dan tidak berbuah, pemahaman petani mengenai budidaya kakao yang masih rendah sehingga belum mampu mengoptimalkan perawatan tanaman dengan baik, unit pengolah hasil (UPH) kakao yang belum berfungsi optimal, umur panen yang tidak seragam, proses fermentasi yang tidak sesuai standar teknis, serta tidak adanya pengawasan mutu kakao. Dengan adanya berbagai kendala tersebut meyebabkan pendapatan petani menurun, untuk mengatasi hal tersebut diperlukan optimalisasi sumberdaya mulai dari budidaya (on farm) sampai dengan pengolahannya (off farm) salah satunya dengan kegiatan pengembangan model desa kakao.

Pengembangan model desa kakao merupakan suatu model unggulan yang 
dikembangkan untuk meningkatkan kesejahteraan masyarakat pedesaan dengan produk unggulan berbasis kakao. Pengelolaan tanaman kakao dilakukan dari hulu hingga ke hilir. Penataan dilakukan pada pola sistem budidaya serta pengelolaan terhadap penambahan daya saing dan nilai tambah produk kakao. Prinsip kegiatan ini adalah menjadikan suatu kawasan kakao sebagai kawasan model percontohan (Anonim, 2013).

Pengembangan model desa kakao ini mengubah cara budidaya kakao yang selama ini petani terapkan untuk memperbaiki produktivitas dan mutu kakao yang dihasilkan yang pada akhirnya diharapkan mampu meningkatkan pendapatan petani kakao. Kegiatan yang dilakukan dalam pengembangan model desa kakao ini adalah optimalisasai budidaya kakao (on farm), pengolahan dan pasca panen kakao (offfarm), serta penguatan kelembagaan dan sumber daya manusia. Kegiatan on farm antara lain: pengaturan jarak tanam, pengurangan pohon penaung, pemangkasan berat, sanitasi, pemupukan, dan pengendalian organisme pengganggu tanaman. Kegiatan offfarm antara lain: fermentasi, pengolahan hasil samping, pembuatan pupuk organik, penjualan kakao yang tersentra di kelompok tani. Penguatan kelembagaan dan sumber daya manusia antara lain: pelatihan pengelolaan kakao fermentasi, pelatihan dinamika kelompok, pelatihan kelembagaan, dan sekolah lapang pengendalian hama terpadu.
Keberhasilan pelaksanaan pengembangan model desa kakao akan tercapai apabila tercipta partisipasi aktif anggota kelompok tani sasaran, partisipasi aktif di sini dimaknai dengan keikutsertaan petani secara sadar dan tanpa paksaan untuk turut andil dan berperan serta dalam pelaksanaan pengembangan model desa kakao mulai dari kegiatan on farm, off farm, serta penguatan sumber daya manusia dan kelembagaan.

Menurut Mardikanto (2013), partisipasi berasal dari kata participation yang berarti tindakan, peran serta dalam aktivitas suatu kelompok, atau keikutsertaan, dalam hal ini mengacu pada keikutsertaan seseorang dalam sebuah kegiatan tertentu.

Menurut Theodorson (1969) cit Mardikanto (2013), dalam kamus sosiologi disebutkan bahwa partisipasi merupakan keikutsertaan seseorang di dalam kelompok sosial untuk mengambil bagian dari kegiatan masyarakatnya, di luar pekerjaan atau profesinya sendiri.

Keith Davis cit Henryk (2013) mengatakan bahwa partisipasi adalah " as a mental and emotional involvement of person in a group situation which encourages him to contribute to group goals and share responsibility in them". Menurut Erickson (1974) cit. Muslim (2007) partisipasi merupakan manifestasi tanggung jawab sosial dari individu terhadap komunitasnya sendiri maupun dengan komunitas luar. 
Menurut Peranginangin (2014), selama ini, pemerintah kerap mengklaim kebijakannya sudah partisipatif karena telah melalui suatu tahap yaitu publik dikumpulkan dalam suatu forum, padahal forum itu adalah forum sosialisasi dan bukannya forum permusyawaratan. Agar konsultasi publik dapat memberikan hasil yang optimal, maka harus disikapi dengan membuka wadah partisipasi. Selanjutnya Devianti (2013) mengatakan agar tujuan pembangunan dapat terwujud maka peran serta dan kerja sama dari seluruh masyarakat yang ada sangat diperlukan sekali, karena salah satu faktor yang menentukan dalam terlaksananya suatu pembangunan adalah faktor manusia itu sendiri.

Simanjuntak (1986) cit Ibrahim (2013) menyebutkan berdasarkan jenis sumbangannya ada beberapa bentuk partisipasi, yaitu :

a. Partisipasi buah pikiran (ide), yang diberikan pada waktu rapat

b. Partisipasi tenaga, yang diberikan pada perbaikan/pembangunan

c. Partisipasi harta benda, yang diberikan pada kegiatan pertolongan

Menggerakkan partisipasi masyarakat bukan hanya esensial untuk mendukung kegiatan pembangunan oleh pemerintah, tetapi juga agar masyarakat berperan lebih besar dalam kegiatan yang dilakukannya sendiri (Judiono, 2009). Agar petani memiliki partisipasi yang aktif dalam pengembangan model desa kakao diperlukan peran petugas lapang. Petugas lapang merupakan seorang agen perubahan (change agent) yang bertugas untuk mempengaruhi proses pengambilan keputusan petani untuk mengadopsi inovasi. Menurut Mardikanto (2009) cit Narso (2012), dalam perkembangannya peran penyuluh tidak hanya terbatas pada fungsi menyampaikan inovasi dan mempengaruhi proses pengambilan keputusan yang dilakukan oleh penerima manfaat penyuluhannya, tetapi ia harus bisa menjadi jembatan penghubung antara pemerintah atau lembaga penyuluhan yang diwakilinya dengan masyarakatnya, baik dalam hal menyampaikan inovasi atau kebijakan-kebijakan yang harus diterima dan dilaksanakan oleh masyarakat sasaran, maupun untuk menyampaikan umpan balik atau tanggapan masyarakat kepada pemerintah/lembaga penyuluhan yang bersangkutan.

Penyuluhan sebagai proses demokrasi harus mampu mengembangkan suasana bebas untuk mengembangkan kemampuan masyarakat dengan mengajak sasaran penyuluhan untuk berpikir, berdiskusi, menyelesaikan masalahnya, merencanakan dan bertindak bersama-sama sehingga mampu menyelesaikan masalah dari mereka, oleh mereka, dan untuk mereka (Jafri, 2015).

Peran penyuluhan pertanian adalah perubahan perilaku petani melalui pendidikan, proses perkembangan dirinya 
sebagai individu, hingga memungkinkan dirinya berpartisipasi dalam kehidupan sosial untuk meningkatkan kesejahteraan masyarakat pada umumnya (Risna, 2012).

Undang-Undang No.16 Tahun 2006 tentang Sistem Penyuluhan Pertanian, Perikanan, dan Kehutanan penyuluh pertanian merupakan petugas lapangan yang berpengalaman di bidang penyuluhan pertanian dengan tugas utama melakukan fasilitasi dan membantu hambatan teknis yang dialami oleh petani serta fungsi-fungsi penyuluh lainnya dalam upaya peningkatan pendapatan petani dan perbaikan kesejahteraan keluarga/ masyarakat. Selanjutnya, Mangkuprawira (2010) menjelaskan bahwa penyuluh pertanian sangat dibutuhkan dalam pengembangan masyarakat karena mempunyai fungsi sebagai analis masalah, pembimbing kelompok, pelatih, inovator, dan penghubung.

Dalam penelitian ini diambil lima peran petugas lapang yaitu peran sebagai komunikator, motivator, fasilitator, organisator dan konsultan.

1. Komunikator, yaitu peranan penyuluh pertanian dalam membantu petani membentuk pendapat yang sehat dan membuat keputusan yang baik dengan cara berkomunikasi dan memberikan informasi yang mereka perlukan (Ibrahim, et al., 2003).

2. Motivator, yaitu seorang penyuluh dapat membimbing dan memotivasi para petani agar mau mengubah cara berfikir dan cara kerjanya agar timbul keterbukaan dan mau menerapkan caracara bertani baru yang lebih berdaya guna dan berhasil guna (Ibrahim, et al., 2003).

3. Fasilitator, yaitu seorang penyuluh diharapkan mampu menjembatani petani dalam menganalisis kekuatan, kelemahan, peluang dan kesempatan yang ada pada diri petani sendiri maupun yang terdapat pada usahataninya (Ibrahim, et al., 2003).

4. Selain itu, penyuluh juga membantu memfasilitasi petani untuk memperoleh keperluan-keperluan yang mereka butuhkan seperti sarana produksi, dan informasi.

5. Organisator, menurut Mardikanto (2009) cit Narso (2012) organisator yaitu mampu menjalin hubungan baik dengan segenap lapisan masyarakat (terutama tokoh-tokohnya), mampu menumbuhkan kesadaran dan menggerakkan partisipasi masyarakat, mampu berinisiatif bagi terciptanya perubahan-perubahan serta dapat memobilisasi sumberdaya, mengarahkan dan membina kegiatankegiatan maupun mengembangkan kelembagaan-kelembagaan yang efektif untuk melaksanakan perubahanperubahan yang direncanakan

6. Konsultan, yaitu seorang penyuluh memberikan solusi permasalahan 
kepada petani dengan cara tidak memaksakan kehendak, akan tetapi menawarkannya sebagai suatu alternatif pilihan (Ibrahim, et al., 2003).

Permasalahan dalam pengembangan model desa kakao ini adalah kegiatan pengembangan model desa kakao baru dilaksanakan pertama kali di DIY dan melakukan perombakan besar terhadap sistem budidaya tanaman kakao yang selama ini diterapkan oleh petani sehingga partisipasi petani dalam kegiatan tersebut tidak optimal. Target peningkatan produksi kakao tahun 2015 adalah $0,8 \mathrm{~kg}$ kering/pohon, namun pada kenyataannya peningkatan produksi hanya mencapai 0,6 kg kering/pohon. Oleh karena itu peran petugas lapang diperlukan untuk mengoptimalkan partisipasi petani dalam pengembangan model desa kakao. Berdasarkan hal tersebut maka dapat dirumuskan permasalahan sebagai berikut: Bagaimana pengaruh petugas lapang terhadap partisipasi petani dalam pengembangan model desa kakao di Kabupaten Gunungkidul?

\section{METODE PENELITIAN}

Metode dasar penelitian ini adalah deskriptif analitis dengan pendekatan kuantitatif. Lokasi penelitian ditentukan secara purposive di 4 (empat) kelompok tani yang ada di Kecamatan Patuk, Kabupaten Gunungkidul yaitu Kelompok Tani Sari Mulyo (Gambiran, Bunder, Patuk), Kelompok Tani Ngudi Raharjo II
(Plosokerep, Bunder, Patuk), Kelompok Tani Ngudi Subur (Plumbungan, Putat, Patuk) dan Kelompok Tani Sido Dadi (Gumawang, Putat, Patuk). Jumlah sampel yang digunakan 120 responden yang diambil secara simple random sampling. Data dianalisis dengan analisis regresi sederhana.

\section{HASIL DAN PEMBAHASAN}

Petugas lapang dapat berperan sebagai motivator, komunikator, fasilitator, organisator, dan konsultan. Peran petugas lapang dalam kegiatan pengembangan model desa kakao dapat dilihat pada Tabel 1. Secara keseluruhan rata-rata peran petugas lapang adalah $67,10 \%$, yang berarti petugas lapang sering menjalankan perannya dalam pengembangan model desa kakao. Peran petugas lapang sebagai motivator merupakan peran untuk membimbing dan memotivasi para petani untuk menumbuhkan dan mempertahankan semangat petani agar selalu berusaha menerapkan inovasi/ teknologi pengembangan model desa kakao demi meningkatkan kesejahteraan keluarganya. Tabel 1. menunjukkan bahwa rata-rata tingkat peran sebagai motivator adalah sebesar $72,26 \%$ yang berarti petugas lapang sering menjalankan perannya sebagai motivator. Petugas lapang sering berperan dalam memberikan dorongan untuk menjual kakao di kelompok memiliki persentase tertinggi yaitu $76,67 \%$. 
Tabel 1. Peran Petugas Lapang dalam Kegiatan Pengembangan Model Desa Kakao di KabupatenGunungkidul

\begin{tabular}{|c|c|c|c|c|}
\hline No & Indikator & $\begin{array}{l}\text { Interval } \\
\text { Skor }\end{array}$ & $\begin{array}{c}\text { Skor } \\
\text { Rerata }\end{array}$ & $\begin{array}{c}\text { Tingkat } \\
\text { Peran }(\%)\end{array}$ \\
\hline \multicolumn{5}{|c|}{ Motivator } \\
\hline 1. & Memberikan dorongan untuk mengatur jarak tanam & $0-5$ & 3,47 & 69,33 \\
\hline 2. & Memberikan dorongan untuk melakukan pemangkasan & $0-5$ & 3,73 & 74,50 \\
\hline 3. & $\begin{array}{l}\text { Memberikan dorongan untuk melakukan pemupukan dua kali } \\
\text { setahun }\end{array}$ & $0-5$ & 3,73 & 74,50 \\
\hline 4. & $\begin{array}{l}\text { Memberikan dorongan untuk melakukan fermentasi selama } 5 \\
\text { hari }\end{array}$ & $0-3$ & 2,15 & 71,67 \\
\hline 5. & Memberikan dorongan untuk menjual kakao di kelompok & $0-3$ & 2,30 & 76,67 \\
\hline 6. & $\begin{array}{l}\text { Memberikan dorongan untuk mengikuti pelatihan pengembangan } \\
\text { model desa kakao }\end{array}$ & $0-3$ & 2,04 & 68,06 \\
\hline 7. & $\begin{array}{l}\text { Memberikan dorongan untuk bekerjasama dalam kelompok tani } \\
\text { dalam hal budidaya dan pasca panen kakao }\end{array}$ & $0-5$ & 3,58 & 71,50 \\
\hline 8. & $\begin{array}{l}\text { Memberikan dorongan untuk melaksanakan hari kakao secara } \\
\text { rutin }\end{array}$ & $0-3$ & 2,14 & 71,39 \\
\hline \multicolumn{2}{|c|}{ Rerata } & & & 72,26 \\
\hline \multicolumn{2}{|c|}{ Jumlah } & 0-32 & 23,13 & \\
\hline
\end{tabular}

Komunikator

1. Memberikan informasi mengenai anjuran teknologi dalam $\quad 0-4 \quad 2,40 \quad 60,00$ pengembangan model desa kakao

2. Memberikan informasi paket bantuan dalam pengembangan $\quad 0-5 \quad 3,23 \quad 64,67$ model desa kakao

3. Memberikan informasi untuk menjual kakao di kelompok $\quad 0-5 \quad 4,18 \quad 83,50$

4. Memberikan informasi pelaksanaan pelatihan pengembangan $\quad \begin{array}{lll}0-4 & 2,18 & 54,58\end{array}$ model desa kakao

5. Memberikan informasi pelaksanaan hari kakao $\quad 0-4 \quad 2,16 \quad 53,96$

6. Menyampaikan penyuluhan yang berkaitan dengan pengembangan $\quad 0-5 \quad 3,95 \quad 79,00$ model desa kakao sesuai dengan kebutuhan petani

7. Menyampaikan penyuluhan yang berkaitan dengan $\quad 0-5 \quad 3,93 \quad 78,50$ pengembangan model desa kakao secara sistematis

\begin{tabular}{lccc}
\hline Rerata & & & $\mathbf{6 8 , 8 2}$ \\
\hline Jumlah & $\mathbf{0 - 3 2}$ & $\mathbf{2 2 , 0 3}$ & \\
\hline Fasilitator & & & \\
1. Mendampingi petani dalam menerapkan teknis budidaya kakao & $0-4$ & 2,11 & 52,71 \\
$\quad$ sesuai anjuran dalam pengembangan model desa kakao & & & \\
2. Mendampingi dalam pemasaran kakao & $0-3$ & 1,09 & 36,39 \\
3. Mendampingi petani dalam fermentasi kakao & $0-3$ & 1,08 & 35,83 \\
4. Membantu petani dalam memperoleh alat pangkas & $0-4$ & 2,33 & 58,33 \\
5. Membantu petani dalam memperoleh unit pengolah hasil dan & $0-4$ & 2,22 & 55,42 \\
$\quad$ kotak fermentasi & & & \\
6. Membantu petani dalam memperoleh bibit dan pupuk & $0-4$ & 2,42 & 60,42 \\
\hline Re.rata & $\mathbf{0 - 2 2}$ & $\mathbf{1 1 , 2 4}$ & $\mathbf{5 1 , 1 0}$ \\
\hline Jumlah & &
\end{tabular}


Lanjutan Tabel 1.

\begin{tabular}{|c|c|c|c|c|}
\hline No & Indikator & $\begin{array}{l}\text { Interval } \\
\text { Skor }\end{array}$ & $\begin{array}{l}\text { Skor } \\
\text { Rerata }\end{array}$ & $\begin{array}{l}\text { Tingkat } \\
\text { Peran }(\%)\end{array}$ \\
\hline & Menggerakkan petani untuk menerapkan teknis budidaya kakao & $0-5$ & 3,98 & 79,50 \\
\hline & Mengarahkan petani untuk melakukan fermentasi selama 5 hari & $0-4$ & 2,08 & 52,08 \\
\hline & Menyadarkan petani untuk menjual kakao di kelompok & $0-5$ & 4,00 & 80,00 \\
\hline & Membina kelompok tani & $0-4$ & 2,32 & 57,92 \\
\hline & $\begin{array}{l}\text { Menggerakkan petani untuk melaksanakan hari kakao secara } \\
\text { rutin }\end{array}$ & $0-4$ & 2,98 & 74,38 \\
\hline \multicolumn{2}{|c|}{ Rerata } & & & 69,77 \\
\hline & & $0-22$ & 15,35 & \\
\hline Jumlah & isultan & & & \\
\hline \multicolumn{2}{|r|}{$\begin{array}{l}\text { 1. Memberikan solusi dalam pengendalian organisme pengganggu } \\
\text { tanaman }\end{array}$} & $0-5$ & 4,00 & 80,00 \\
\hline \multirow{3}{*}{\multicolumn{2}{|c|}{$\begin{array}{l}\text { 2. Memberikan solusi mengenai fermentasi kakao } \\
\text { 3. Memberikan solusi pemasaran kakao } \\
\text { 4. Memberikan solusi mengenai kendala dalam pelaksanaan hari } \\
\text { kakao }\end{array}$}} & $0-5$ & 4,03 & 80,50 \\
\hline & & $0-4$ & 2,03 & 50,84 \\
\hline & & $0-4$ & 2,74 & 68,54 \\
\hline \multirow{2}{*}{\multicolumn{2}{|c|}{ Rerata }} & & & 71,11 \\
\hline & & $0-18$ & 12,80 & \\
\hline Jumlah & ata Total & & & 67,10 \\
\hline \multicolumn{2}{|c|}{ Jumlah Total } & $0-126$ & 84,54 & \\
\hline
\end{tabular}

Sumber : Analisis Data Primer, 2016

Peran petugas lapang sebagai komunikator merupakan peran untuk menyampaikan informasi yang berkaitan dengan kegiatan pengembangan model desa kakao kepada anggota kelompok tani agar diterima dengan baik dan dilaksanakan. Tabel 1 menunjukkan bahwa rata-rata tingkat peran sebagai komunikator adalah sebesar $68,82 \%$, yang berarti petugas lapang sering menjalankan perannya sebagai komunikator. Peran petugas lapang memberikan informasi untuk menjual kakao di kelompok memiliki persentase tertinggi yaitu $83,50 \%$. Petugas lapang sangat sering memberikan informasi untuk menjual kakao di kelompok tani, hal ini dilakukan agar kualitas kakao yang dihasilkan petani meningkat karena dengan menjual biji kakao basah ke kelompok tani, maka fermentasi dilakukan oleh kelompok tani sehingga hasil fermentasi dapat sesuai standar teknis dan harga biji kakao kering menjadi lebih mahal.

Peran petugas lapang sebagai fasilitator merupakan peran untuk memfasilitasi petani memperoleh keperluan-keperluan yang mereka butuhkan seperti sarana produksi dan informasi yang berkaitan dengan pengembangan model desa kakao. Menurut Karsidi (2001), penyuluh menyadari perannya sebagai fasilitator dan bukannya sebagai pelaku atau guru. Untuk itu, perlu sikap rendah hati serta ketersediaan untuk belajar dari masyarakat dan menempatkan warga masyarakat sebagai narasumber utama 
dalam memahami keadaan masyarakat itu.

Tabel 1. menunjukkan bahwa rata-rata tingkat peran sebagai fasilitator adalah sebesar $51,10 \%$ yang termasuk dalam kategori kadang-kadang. Persentase yang paling tinggi sebesar $60,42 \%$ adalah petugas lapang sering berperan dalam membantu petani memperoleh bibit dan pupuk, sedangkan peran petugas lapang yang terendah adalah jarang mendampingi petani melakukan fermentasi kakao dengan persentase sebesar 35,83\%. Dalam melakukan perannya sebagai fasilitator, petugas lebih sering membantu petani untuk memperoleh sarana produksi seperti bibit dan pupuk dan memastikan bahwa sarana produksi tersebut tepat sasaran, dalam artian benar-benar digunakan untuk memupuk kakao, sedangkan pendampingan petani pada saat melakukan fermentasi jarang dilakukan oleh petugas lapang karena pada umumnya petugas lapang memberikan informasi cara fermentasi yang sesuai standar teknis pada saat pelatihan kemudian mempraktekkan pada saat pelatihan tersebut. Setelah petani dirasa mampu untuk melakukan fermentasi yang benar, maka petani secara mandiri melakukan fermentasi di kelompok tani.

Peran petugas lapang sebagai organisator merupakan peran untuk mampu menumbuhkan kesadaran dan menggerakkan partisipasi petani, mengarahkan dan membina kegiatan-kegiatan di dalam kelompok tani maupun mengembangkan kelembagaankelembagaan yang efektif untuk tujuan kelompok. Tabel 1. menunjukkan bahwa rata-rata tingkat peran sebagai organisator adalah sebesar $69,77 \%$, yang berarti petugas lapang sering menjalankan perannya sebagai organisator. Petugas lapang sering berperan dalam menyadarkan petani untuk menjual kakao di kelompok dengan persentase sebesar $80 \%$. Petugas lapang selalu menyadarkan petani untuk menjual kakao di kelompok agar kualitas biji kakao kering fermentasi meningkat dan harga kakao kering fermentasi menjadi lebih tinggi.

Peran petugas lapang sebagai konsultan merupakan peran untuk memberikan solusi permasalahan kepada petani yang berhubungan dengan pengembangan model desa kakao dengan

Tabel 2. Sebaran Kategori Tingkat Peran Petugas Lapang dalam Pengembangan Model Desa Kakao di Kabupaten Gunungkidul

\begin{tabular}{clrr}
\hline No & \multicolumn{1}{c}{ Kategori Peran } & Jumlah Petani (orang) & Persentase (\%) \\
\hline 1 & Tidak pernah (0-24) & 0 & 0 \\
2 & Jarang (25-50) & 1 & 0,83 \\
3 & Kadang-kadang (51-76) & 31 & 25,83 \\
4 & Sering (77-102) & 74 & 61,67 \\
5 & Sangat sering (102-126) & 14 & 11,67 \\
\hline Jumlah & 120 & 100 \\
\hline
\end{tabular}

Sumber : Analisis Data Primer, 2016 
Tabel 3. Partisipasi Petani dalam Pengembangan Model Desa Kakao di Kabupaten Gunungkidul

\begin{tabular}{clccc}
\hline No & Bentuk Partisipasi & Interval Skor & Skor Rerata & Tingkat partisipasi (\%) \\
\hline 1. & Ide & $0-41$ & 23,13 & 56,17 \\
2. & Tenaga & $0-40$ & 26,08 & 64,30 \\
3. & Dana & $0-9$ & 5,03 & 55,93 \\
\hline Rerata & & & 60,25 \\
\hline Jumlah & $0-90$ & 54,23 & \\
\hline
\end{tabular}

Sumber : Analisis Data Primer, 2016

cara tidak memaksakan kehendak, akan tetapi menawarkannya sebagai suatu alternatif pilihan. Tabel 1. menunjukkan bahwa rata-rata tingkat peran sebagai konsultan adalah sebesar $71,11 \%$ yang berarti petugas lapang sering menjalankan perannya sebagai konsultan. Persentase yang paling tinggi sebesar $80,50 \%$ adalah petugas lapang sangat sering berperan dalam memberikan solusi dalam pengendalian organisme pengganggu tanaman. Petugas lapang sangat sering memberikan solusi permasalahan mengenai pengendalian organisme pengganggu tanaman yang menyerang kakao terutama penyakit busuk buah dan helopeltis.

Peran petugas lapang dalam pengembangan model desa kakao dikategorisasikan menjadi lima tingkatan, mulai dari tidak pernah, jarang, kadangkadang, sering, dan sangat sering yang dapat dilihat pada Tabel 2.

Berdasarkan Tabel 2. dapat dilihat bahwa peran petugas lapang dinilai oleh petani dalam kategori sering $(61,67 \%)$. Hal ini menunjukkan bahwa petugas lapang sudah menjalankan perannya sebagai motivator, komunikator, fasilitator, organisator, dan konsultan dengan baik. Dengan adanya peran petugas lapang yang baik ini, diharapkan akan meningkatkan partisipasi petani dalam pengembangan model desa kakao yang pada akhirnya akan mencapai keberhasilan pada pengembangan model desa kakao tersebut.

Partisipasi petani dalam pengembangan model desa kakao diwujudkan dalam bentuk partisipasi ide, partisipasi tenaga, dan partisipasi dana. Hasil pengukuran variabel partisipasi dapat dilihat pada Tabel 3.

Rerata partisipasi petani adalah sebesar $60,25 \%$ yang berarti bahwa petani sering berpartisipasi dalam kegiatan pengembangan model desa kakao. Guna mengukur pengaruh peran petugas lapang terhadap partisipasi petani dalam pengembangan model desa kakao di Kabupaten Gunungkidul dianalisis menggunakan regresi linier sederhana. Hasil analisis regresi sederhana dapat dilihat pada Tabel 4. 
Berdasarkan Tabel 4 menunjukkan bahwa $<<0,05$ sehingga peran petugas lapang berpengaruh nyata terhadap partisipasi petani dalam pengembangan model desa kakao di Kabupaten Gunungkidul.

Nilai Adjusted $R$ square yaitu sebesar 0,316. Hal ini berarti 31,6\% variabel partisipasi petani dapat dijelaskan oleh variabel peran petugas lapang, sedangkan $68,4 \%$ sisanya dijelaskan oleh faktor-faktor lain di luar model. Nilai $F$ hitung adalah 58,854 dengan $\mathrm{p}<0,05$ menunjukkan bahwa variabel peran petugas lapang berpengaruh terhadap variabel partisipasi petani dalam pengembangan model desa kakao.

Tabel 4. Hasil Analisis Regresi Linier Sederhana

\begin{tabular}{lccc}
\hline Variabel & $\begin{array}{c}\text { Koofisien } \\
\text { Regresi }\end{array}$ & T hitung & Signifikansi \\
\hline Peran & 0,558 & 7,474 & $0,000^{*}$ \\
Petugas & & & \\
lapang & & & \\
\hline
\end{tabular}

Sumber : Analisis Data Primer, 2016

Keterangan :

Konstanta : 7,070

$\mathrm{R}: 0,567$

R Square : : 0,321

Adjusted

R Square $\quad: 0,316$

F hit $\quad: 55,854$

* $\quad$ : signifikansi pada taraf $5 \%$

Berdasarkan analisis regresi linier sederhana seperti pada Tabel 4 diperoleh persamaan regresi sebagai berikut :

$$
\mathrm{Y}=7,070+0,558 \mathrm{X}
$$

Keterangan :

$\mathrm{Y}=$ partisipasi petani dalam

pengembangan model desa kakao

$\mathrm{X}=$ peran petugas lapang

Grafik persamaan regresi linear sederhana dapat dilihat pada Gambar 1.

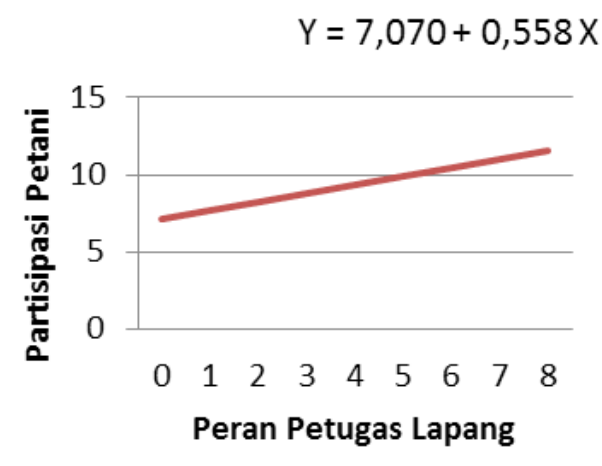

Gambar 1. Grafik Pengaruh Peran Petugas Lapang terhadap Partisipasi Petani dalam Pengembangan Model Desa Kakao

Berdasarkan persamaan regresi dan Gambar 1. dapat diartikan bahwa peran petugas lapang berpengaruh positif $(+)$ terhadap partisipasi petani dalam pengembangan model desa kakao yaitu semakin sering petugas lapang menjalankan perannya, maka partisipasi petani dalam pengembangan model desa kakao akan semakin meningkat. Pengaruh positif diartikan sebagai penambahan nilai variabel independent $(\mathrm{X})$ akan menaikkan variabel dependent $(\mathrm{Y})$, dalam hal ini satu satuan unit penambahan peran petugas lapang akan meningkatkan partisipasi 
petani dalam sebanyak 0,558 satuan unit. Jika peran petugas lapang adalah nol satuan unit atau tidak ada, maka nilai tingkat partisipasi petani adalah 7,070 satuan unit.

Petugas lapang adalah bagian yang sangat penting dalam mendukung pelaksanaan pengembangan model desa kakao. Menurut Wastika (2014), penyuluh yang mampu menjalankan perannya mendampingi kelompok tani akan menggerakkan petani anggota untuk berperan aktif dalam kelompok dan menerapkan inovasi yang disampaikan penyuluh.

Peran petugas lapang dalam pengembangan model desa kakao ini adalah sebagai motivator, komunikator, fasilitator, organisator, dan konsultan. Semakin sering petugas lapang berperan untuk mendorong petani, memberikan informasi, menghubungkan petani dengan sumber informasi, mengorganisir petani, dan memberikan solusi mengenai permasalahn kakao yang sedang dihadapi petani, maka partisipasi petani dalam pengembangan model desa kakao akan semakin meningkat. Hal ini dikarenakan semakin sering petugas lapang berperan, maka sikap dan perilaku petani dapat diubah untuk mendukung pengembangan model desa kakao dan pada akhirnya akan ikut serta dalam kegiatan tersebut.

Peran petugas lapang yang potensial untuk meningkatkan partisipasi petani dalam pengembangan model desa kakao adalah memberikan dorongan, memberikan informasi, mengarahkan, dan menyadarkan petani untuk menjual kakao di kelompok tani. Hal ini memiliki andil yang besar dalam meningkatkan partisipasi petani dikarenakan dengan menjual kakao di kelompok tani maka petani sudah memiliki kesadaran dan komitmen untuk memajukan kelompok tani. Dengan penjualan yang tersentra di kelompok tani, kualitas kakao fermentasi yang dihasilkan akan lebih baik dan seragam, meningkatkan kas kelompok dan meningkatkan bargaining position biji kakao kering fermentasi.

Salah satu tujuan kegiatan pengembangan model desa kakao dalah terwujudnya kakao fermented dengan kualitas Standar Nasional Indonesia (SNI). Daya saing ekspor biji kakao Indonesia cukup kompetitif, Indonesia masih mempunyai peluang untuk meningkatkan ekspor dan mengembangkan pasar domestic (Rubiyo, 2012). Produksi biji kakao Indonesia secara signifikan terus meningkat, namun mutu yang dihasilkan sangat rendah dan beragam, antara lain kurang terfermentasi, tidak cukup kering, ukuran biji tidak seragam, keasaman tinggi, cita rasa sangat beragam dan tidak konsisten. Hal tersebut tercermin dari harga biji kakao Indonesia yang relatif rendah dan dikenakan potongan harga dibandingkan dengan harga produk sama dari negara produsen lain. Beberapa faktor penyebab mutu kakao beragam yang dihasilkan adalah minimnya sarana pengolahan, lemahnya pengawasan 
mutu serta penerapan teknologi pada seluruh tahapan proses pengolahan biji kakao yang tidak berorientasi pada mutu. Kriteria mutu biji kakao yang meliputi aspek fisik, cita rasa dan kebersihan serta aspek keseragaman dan konsistensi sangat ditentukan oleh perlakuan pada setiap tahapan proses produksinya. Selain itu pengawasan dan pemantauan setiap tahapan proses harus dilakukan secara rutin agar tidak terjadi penyimpangan mutu. Proses pengolahan buah kakao menentukan mutu produk akhir kakao, karena dalam proses ini terjadi pembentukan calon cita rasa khas kakao dan pengurangan cita rasa yang tidak dikehendaki, misalnya rasa pahit dan sepat. Dengan adanya peran petugas lapang yang mendorong petani untuk menjual biji kakao ke kelompok tani dapat mewujudkan tujuan kegiatan pengembangan model desa kakao yaitu terwujudnya kakao fermented dengan kualitas SNI karena proses fermentasi dilakukan secara seragam oleh kelompok, sehingga kualitas biji kakao fermentasi yang dihasilkan akan lebih baik.

Slamet (1985) cit Mardikanto (2013) mengatakan bahwa tumbuh dan berkembangnya partisipasi sangat ditentukan oleh 3 (tiga) unsur pokok, yaitu :

1. Adanya kemauan yang diberikan untuk berpartisipasi

2. Adanya kesempatan untuk berpartisipasi

3. Adanya kemampuan untuk berpartisipasi Tugas petugas lapang untuk meningkatkan partisipasi petani adalah dengan melakukan pendampingan agar petani memiliki kemauan, memiliki kesempatan, dan memiliki kemampuan untuk berpartisipasi dalam pengembangan model desa kakao sehingga kegiatan tersebut dapat berhasil sesuai dengan yang sudah direncanakan, agar petani dapat memiliki kemauan untuk berpartisipasi maka petugas lapang dapat melakukan persuasi atau memotivasi petani untuk ikut serta dalam kegiatan pengembangan model desa kakao dan memberikan penjelasan mengenai keuntungan yang akan diperoleh apabila ikut berperan serta dalam kegiatan pengembangan model desa kakao tersebut. Petani diberikan kesempatan untuk berpartisipasi dan didukung partisipasinya yang berarti bahwa setiap kegiatan dalam pengembangan model desa kakao harus melibatkan petani. Petani dapat ditingkatkan kapasitas dan kemampuannya untuk berpartisipasi dalam pengembangan model desa kakao dengan cara memberikan pelatihan teknis budidaya maupun penguatan kelembagaan kelompok tani.

\section{KESIMPULAN DAN SARAN Kesimpulan}

Peran petugas lapang berpengaruh positif terhadap partisipasi petani, semakin sering petugas lapang berperan sebagai motivator, komunikator, fasilitator, organisator dan konsultan, maka partisipasi petani dalam pengembangan model desa kakao akan semakin meningkat. 


\section{Saran}

Petugas lapang hendaknya meningkatkan perannya sebagai fasilitator dengan cara selalu mendampingi petani dalam fermentasi kakao, mendampingi petani dalam pemasaran kakao, mendampingi petani dalam menerapkan teknis budidaya kakao, membantu petani dalam memperoleh alat pangkas, dan membantu petani dalam memperoleh kotak fermentasi dan unit pengolah hasil kakao.

Peran petugas lapang yang paling krusial untuk ditingkatkan yaitu mendampingi petani dalam fermentasi kakao dari kategori jarang mendampingi menjadi sangat sering mendampingi. Pendampingan fermentasi kakao perlu ditingkatkan karena dengan adanya pendampingan tersebut, fermentasi yang dilakukan oleh petani akan sesuai dengan standar teknis yang ada sehingga kualitas kakao akan meningkat dan dapat meningkatkan harga kakao kering fermentasi.

\section{DAFTAR PUSTAKA}

Anonim. 2013. Grand Design Pengembangan Model Desa Kakao DIY Tahun 2014-2017. Dinas Kehutanan dan Perkebunan DIY.

Deviyanti, D. 2013. Studi Tentang Partisipasi Masyarakat dalam Pembangunan di Kelurahan Karang
Jati Kecamatan Balikpapan Tengah. eJournal Administrasi Negara 1 (2) : 380-394.

Henryk. S. 2013. Partisipasi Masyarakat dalam Pembangunan di Kelurahan Sungai Keledang Kecamatan Samarinda Seberang Kota Samarinda. eJournal Ilmu Pemerintahan1 (2): 612-625.

Ibrahim, J.T., Sudiyono, A., dan Harpowo. 2003. Komunikasi dan Penyuluhan Pertanian. Bayumedia Publishing, Malang: UMM Press.

Jafri, J., Rudi Febriamansyah, Rahmat Syahni, dan nFN Asmawi. 2015. Interaksi Partisipatif antara Penyuluh Pertanian dan Kelompok Tani Menuju Kemandirian Petani. Jurnal Agro Ekonomi 33 (2): 161-177.

Juniono, F. 2009. Partisipasi Masyarakat dalam Pembangunan Prasarana Jalan Studi Kasus Peningkatan Jalan di Desa Sambirejo, Kecamatan Tanjunganom, Kabupaten Nganjuk. Wacana 12 (3): 579-591.

Karsidi, R. 2001. Paradigma Baru Penyuluhan Pembangunan dalam Pemberdayaan Masyarakat. Mediator 1242 (1) : 115-125.

Mangkuprawira, S. 2010. Strategi Peningkatan Kapasitas Modal 
Sosial dan Kualitas Sumber Daya

Manusia Pendamping Pembangunan

Pertanian. Forum Penelitian Agro

Ekonomi 28(1):19-34.

Mardikanto, T. dan Soebiato, P., 2013, Pemberdayaan Masyarakat Dalam Perspektif Kebijakan Publik. Bandung : Alfabeta.

Muslim, A., 2007, Pendekatan Partisipastif dalam Pemberdayaan Masyarakat. Aplikasia Jurnal Aplikasi llmu-ilmu Agama VIII (2) : 89-103.

Narso, Amiruddin Saleh, Pang S Asngari, dan Pudji Muljono. 2012. Strategi Pengembangan Peran Penyuluh Pertanian Lapang di Provinsi Banten. Jurnal Penyuluhan 8 (2) : 176-183.

Peranginangin, L.S.U., 2014. Partisipasi Masyarakat dalam Pengelolaan Kawasan Konservasi. Jurnal
Kebijakan \& Administrasi Publik JKAP 18 (1).

Risna, Masyhudah Rosni, dan Mariani. 2012. Peran Penyuluhan Pertanian terhadap Pengendalian Hama Terpadu pada Tanaman Padi Berdasarkan Kelas Kemampuan Kelompok Tani di Kecamatan Labuan Amas Selatan Kabupaten Hulu Sungai Tengah. Jurnal Agribisnis Perdesaan 2 (3): 214-228.

Rubiyo dan Siswanto, 2012. Peningkatan Produksi dan Pengembangan Kakao (Theobroma Cacao L.) di Indonesia. Buletin RISTRI 3 (1) 2012.

Wastika, C.H., Hariadi, S.S., dan Subejo. 2014. Peran Kelompok Tani dalam Penerapan SRI (System Of Rice Intensification) di Kecamatan Kalikajar Kabupaten Wonosobo. Agro Ekonomi 24 (1) : 84-93. 